\title{
Chapter 29 \\ Studies on body image, eating, and weight in models, dancers, and aesthetic athletes
}

\section{Rita Francisco}

Universidade Católica Portuguesa, School of Human Sciences, Lisboa, Portugal

ritafrancisco@ucp.pt

\begin{abstract}
Fashion models, dancers and aesthetic athletes are considered high-risk groups for the development of body image concerns and eating disorders. In all these aesthetic activities, physical appearance is seen as fundamental and lean bodies are required. Therefore, these contexts are considered subcultures in which social pressures to be thin are reinforced.

Even for the least investigated group among the aesthetic activities, fashion models, the few existing studies indicate that they present higher levels of disordered eating but also higher levels of body satisfaction and self-esteem than control groups. Professional ballet dancers are considered at greater risk than recreational dancers since the rule "thinness $=$ success" seems to be implicitly and explicitly transmitted by many different means (especially critical comments by teachers and peers about eating, weight and shape). Among aesthetic athletes (e.g., gymnasts, synchronized swimmers, figure skaters), the desire to be leaner to improve sports performance seems to mediate the relationship between social pressure from the sports environment and disordered eating. This desire is especially related to sports-related body dissatisfaction (higher than general body dissatisfaction), which is considered a strong predictor of disordered eating for these athletes.

In this chapter, we review different studies of these specific groups to gain a better understanding of how fashion models, dancers and aesthetic athletes address their eating and body image and to identify the specific factors associated with the development of body image concerns and eating disorders.
\end{abstract}

Keywords: body image, weight, eating, pressure for thinness, body dissatisfaction, eating disorders, fashion models, dancers, aesthetic athletes 


\subsection{Introduction}

In aesthetic activities - which include fashion, dance and aesthetic sports (e.g., gymnastics, synchronized swimming or figure skating) - physical appearance is considered fundamental and lean bodies are required. For these reasons, they are considered high-risk contexts for the development of body image concerns and eating disorders (ED), as several studies of populations around the world have shown since the 1980s. Garner and Garfinkel (1) were the first to examine a population of female professional dance students and fashion models. The authors found that excessive dieting concerns and ED were overrepresented in the dance and modelling students compared to music students and normal controls. Especially at the elite level, in addition to the aesthetic and artistic components of these activities, the competitive aspects become essential in the pursuit of perfection and success and in overcoming the limits of the body (2-4). However, it is important to keep in mind the multifactorial conception of body image concerns and ED, since the individual, family and socio-cultural variables all contribute to their development. Some contributory factors appear to be necessary for the appearance of these kinds of problems, but no single factor is sufficient to explain them (5). Therefore, the contexts of fashion, dance or aesthetic sports can be considered subcultures in which social pressures to be thin are reinforced; thus, their practitioners are frequently encouraged to adopt unhealthy eating and weight control behaviors $(6-10)$ in the incessant search for perfection. The perfection of movement is the perfection of the body; in this sense, the body is often worked to exhaustion in an attempt to achieve the ideal form, which is also the leanest possible (11). However, the requirements in each of these specific contexts are different, particularly in terms of body image. For example, gymnasts are required, above all, to be short, lean and muscular, while dancers are expected to be thin, light and delicate. In turn, fashion models should be tall and slender. Thus, it is important to understand better how fashion models, dancers and aesthetic athletes 
address their eating and body image, the protective and risk factors for the development of body image concerns and ED, and the incidence of these problems in these contexts. Tables 1, 2 and 3 summarize the empirical studies reviewed in this chapter on fashion models, dancers and aesthetic athletes, respectively.

\subsection{Models}

Despite some important initiatives - for example, a Madrid Fashion Week ban of models with an excessively low body mass index (BMI) (12) or the recent law passed by the French parliament that models must have a medical certificate to prove that they are a healthy weight (13) - and a flood of media coverage of the debates subsequent to the deaths of young models as a result of complications of ED (14), fashion models continue to be "so unrepresentative of the everyday woman that they are offensive" $(15, p .22)$. Most of them are far too slender and have a hazardously low BMI, especially as a consequence of pressure from agencies to lose weight, as recently revealed by Erin Heatherton, a famous former Victoria's Secret model (16).

As noted in a recent systematic review of the literature, there are few studies on body image and ED among fashion models. In addition, relatively small samples and frequently low response rates of fashion models limit the generalization of any conclusions (17). However, the existing studies may help us to understand this population better. Compared to non-models, female fashion models often report more disordered eating $(1,18,19)$, and this is especially true for partial-syndromes ED since full syndromes are often not statistically more prevalent $(18,19)$. However, fashion models are on average slightly underweight with significantly lower BMI than controls, report more dysfunctional investment in their appearance, and even desire to become thinner. These worrisome indicators are considered to be associated with the intense competitiveness of the fashion world and with the widespread 
methods used to control weight, which are thought to be too prevalent in the world of top models (18).

Nevertheless, compared to controls, models seem to report higher levels of body satisfaction $(18,20)$ or no differences $(10)$. For female (but not for male) models, body satisfaction was associated to self-esteem (20), which can derive from conforming to societal and industry ideals. Self-esteem can buffer against the development of body image disturbances (10) or ED (19), considering the great pressure to maintain a thin shape to continue to work (17).

\subsection{Dancers}

Ballet is considered an art by those who practise it but is also the most physical of the performing arts (21), which is why dancers are also considered special athletes.

Contemporary dance is rarely included in studies on body image and ED, because of the lesser demands made on these dancers to be thin and the greater acceptance of diversity in terms of body shape and weight. Thus, the lower incidence of constraints and restrictions, both physical and artistic (22), seems to place contemporary dancers at lower risk of developing ED. For example, Schluger (23) found twice the prevalence of disturbed eating behaviors in ballet dancers than in modern dancers (24.4\% vs. $12.2 \%$ ), and Langdon and Petracca (24) identified more positive body image in modern dancers, when compared with previous samples of ballet dancers.

Even though they have lower BMI than control groups, female ballet dancers and dance students at professional ballet schools frequently present a higher desire to lose weight and greater body image dissatisfaction than female non-dancers (25-27). Consistently, most studies also have found a higher prevalence of ED among ballet dancers than non-dancers $(28,29)$, including the finding that female dancers and individuals with ED are similar in 
measures of eating pathology $(26,30)^{1}$. However, recent research has suggested that the effects of dance participation on body image and disordered eating could also be related to the dancer identity, considering that modern dancers with lower dancer identity had more positive general and dance specific body image (24), or to the dance performance level. When adolescent elite ballet dancers and non-elite dancers were compared, elite dancers appeared more dissatisfied with their bodies (31-33) and had significantly higher levels of disordered eating (2).

The differences reported above seem to be especially related to the perception of the pressure to be thin and to the competitive nature of these contexts. A ballet dancer's extrathin body is looked upon as a sign of ultimate control and professional achievement (7), and the culture of "thinness $=$ success" is widespread. Dancers are motivated by a drive to achieve perfection, and some researchers have found that the higher levels of perfectionism found among them than among non-dancers seem to be encouraged $(26,29)$. A qualitative study of young elite ballet dancers found that this pressure to be thin is viewed as an implicit and an explicit rule among ballet schools and the ballet subculture (9). Diverse studies have confirmed that the pressure to be thin is especially transmitted through critical comments by teachers and peers about eating, weight and shape (34) and that more severe critical comments are associated with higher eating psychopathology through reduced self-esteem (35). In general, the pressure to be thin influences dancers' disordered eating both directly and indirectly through reduced self-esteem and reduced body satisfaction (2).

Another important contextual variable that influences body dissatisfaction and disordered eating among dancers is the perspective towards the success. Those who are

\footnotetext{
1 Studies that include male dancers are scarce; thus, results for gender differences are less congruent. For example, equal proportions of disordered eating were found among female and male talented young dancers from the UK centers for advanced training (63), but other studies have found significantly lower levels among male than female dancers $(2,64)$. These results suggest that further research is warranted.
} 
actively ego-oriented (with an emphasis on social comparison and outcome) tend to display more disordered eating correlates. By contrast, perceptions of task-involving motivational climates (focused on learning and personal development) are associated with higher selfesteem and lower weight-related pressure from peers and teachers (36). However, a more recent study indicates that an ego-involving climate in the dance environment could be more salient for male than for female dancers (37). Future research should further explore these context characteristics, which seem very important for the development of preventive interventions that include teachers and peers, in order to create and improve a climate of mastery (36).

\subsection{Aesthetic athletes}

One of the methodologically more robust prevalence studies was conducted in two phases with all Norwegian elite athletes, between 15 and 39 years of age $(n=1620)$, and a representative sample from the general Norwegian population. This research revealed a higher prevalence of ED (AN, BN or EDNOS, based on clinical interviews) among athletes (both female and male) than in the general population. The prevalence was notably higher among athletes competing in sports that focus on leanness and weight (e.g., aesthetic sports) than athletes competing in other sports and controls (38).

When disordered eating or ED (also related to low energy availability) are associated with amenorrhea and osteoporosis, they represent the presence of a syndrome very common in female athletes - the Female Athlete Triad - with potentially irreversible consequences. This triad is often triggered by extreme diets in response to pressures to achieve an unrealistic body weight or shape, resulting in a deficit of energy, menstrual irregularities and a decrease in bone density that increases the risk of injury $(39,40)$. 
Recently, the International Olympic Committee (IOC) updated and replaced its Consensus Statement, since studies have shown that the clinical phenomenon is a "syndrome resulting from relative energy deficiency that affects many aspects of physiological function including metabolic rate, menstrual function, bone health, immunity, protein synthesis, cardiovascular and psychological health" (41, p.491). Thus, and because the relative energy deficiency also affects men, IOC began to use a new terminology for the overall syndrome Relative Energy Deficiency in Sport (RED-S). RED-S (formerly the "Female Athlete Triad"). ED have consistently been found to be more prevalent among both male and female athletes who compete in leanness sports than athletes from other sports and non-athletes $(6,42-47)$.

Gymnasts (competing in rhythmic, artistic or acrobatic gymnastics) are the most studied group of aesthetic athletes regarding body image and ED (48). Nevertheless, despite some slight differences among some disciplines, studies that also include athletes who practice, for example, figure skating, synchronized swimming and cheerleading show, in general, similar results. The desire to be leaner to improve sports performance is predictive of disordered eating, and it seems to mediate the relationship between social pressure from the sports environment and disordered eating (49). Although previous studies have indicated an equal or slightly more positive body image among athletes than controls (50), more recent studies have focused on sports-related body dissatisfaction (instead of general body dissatisfaction) and identified it as a better predictor of disordered eating among aesthetic athletes $(2,51)$.

The difference between the ideal body image conveyed by society and the one for the practice of a particular sport leads many athletes, especially females, to experience a paradox in relation to their body image (52). As suggested by de Bruin et al. (53), an athlete may be satisfied with his/her body shape and figure in the social environment but not with his/her "sporting" body. In this sense, the fact that male athletes perceive a higher similarity between 
these two images and are less subject to this paradox may be the reason that they frequently present better body image satisfaction than their female counterparts, even when the sporting body image is evaluated $(2,45)$.

For many athletes, sports participation is their life, which potentiates some individual traits that make them vulnerable to the development of ED. Some of these characteristics, manifested by "good athletes", are often encouraged and reinforced in elite sporting environments (54-56). These features are, to some extent, similar to those of AN patients (56): a) perfectionism; b) persistence that leads athletes to train and compete to exhaustion (sometimes to please coaches); c) determination to be the best; d) placing the interests, priorities, and needs of the team before their own; e) tolerance of physical suffering. In addition to these individual traits, some other contextual factors have been identified in the literature as contributing significantly to the development of body image dissatisfaction and ED. Regular weigh-ins (sometimes in front of the whole team and/or public posting of weights) are frequently used by coaches to monitor athletes' physical progress, which may lead both male and female athletes to engage in unhealthy behaviors $(8,9,57)$. At the same time, as we noted previously with dancers, several studies have found that critical comments about eating, weight and shape from coaches are important risk factors for disordered eating $(2,3,8,51,58)$. These two elements are important and visible signs of the pressure to be thin frequently found in these contexts, which was found to be a better predictor of disordered eating among aesthetic athletes than the elite (vs. non-elite) level of competition $(2,59)$. It is possible that high levels of pressure to be thin perceived by aesthetic athletes in their clubs or teams explains the absence of differences in body image dissatisfaction or disordered eating between elite and non-elite athletes, as found in many studies (48). 


\subsection{Conclusion}

Fashion models, dancers and aesthetic athletes are indeed high-risk groups for the development of body image problems and eating disorders, and different individual, relational and contextual factors contribute to that risk. It seems inevitable that thinness will continue to be a "rule" in these three studied contexts since any attempt to bring about change would conflict with the history, values and culture of these pursuits. The problem emerges when thinness is taken to the extreme and places at risk models', dancers' and athletes' health. It is often difficult to find the balance between aesthetic/artistic leanness and the extreme thinness that is in conflict with healthy human limits, and even coaches may have difficulty recognizing the symptoms (60).

Systemic preventive actions - targeting not only models, dancers, and athletes, but also coaches, teachers, support personnel and parents - are necessary for these contexts, similar to Piran's work in a highly competitive professional ballet school for 15 years, with positive long-term effects $(61,62)$. For example, it is essential the promotion of taskinvolving and caring climates in which critical comments about eating, weight and shape are avoided. Such actions should equip fashion models, dancers and athletes with tools to develop a more positive and healthy experience of their body, as well as higher wellbeing, self-esteem and activity-specific body image satisfaction. 


\section{References}

1. Garner D, Garfinkel P. Socio-cultural factors in the development of anorexia nervosa. Psychol Med. 1980;10:647-56.

2. Francisco R, Narciso I, Alarcão M. Specific predictors of disordered eating among elite and non-elite gymnasts and ballet dancers. Int J Sport Psychol. 2012;43:479-502.

3. Kong P, Harris LM. The sporting body: Body image and eating disorder symptomatology among female athletes from leanness focused and nonleanness focused sports. J Psychol. 2015;149:141-60.

4. Scoffier S, Corrion K, D’Arripe-Longueville F. Effects of achievement goals on female aesthetic athletes' disordered eating attitudes. Sci Sport. 2013;28:e151-7.

5. Polivy J, Herman CP. Causes of eating disorders. Annu Rev Psychol. 2002;53:187213.

6. Byrne SM, McLean N. Elite athletes: Effects of the pressure to be thin. J Sci Med Sport. 2002;5:80-94.

7. Gvion L. Dancing bodies, decaying bodies: The interpretation of anorexia among Israeli dancers. Young. 2008;16(1):67-87.

8. Kerr G, Berman E, De Souza MJ. Disordered eating in women's gymnastics: Perspectives of athletes, coaches, parents, and judges. J Appl Sport Psychol. $2006 ; 18: 28-43$.

9. Francisco R, Alarcão M, Narciso I. Aesthetic sport as high-risk context for eating disorders: Young elite dancers and gymnasts perspectives. Span J Psychol. $2012 ; 15: 265-74$.

10. Swami V, Szmigielska E. Body image concerns in professional fashion models: Are they really an at-risk group? Psychiatry Res. 2013;207:113-7.

11. Aalten A. Listening to the dancer's body. Sociol Rev. 2007;55:109-25. 
12. CNN. Skinny models banned from catwalk. 2006; Available from: http://edition.cnn.com/2006/WORLD/europe/09/13/spain.models/

13. Willsher K. Models in France must provide doctor's note to work. The Guardian [Internet]. 2015; Available from:

https://www.theguardian.com/world/2015/dec/18/models-doctors-note-prove-not-toothin-france

14. Soltis CA. Dying to be a supermodel: Can requiring a healthy BMI be fashionable? J Contemp Health Law Policy. 2013;26(1):49-71.

15. Mears A. Size zero high-end ethnic: Cultural production and the reproduction of culture in fashion modeling. Poetics. 2010;38:21-46.

16. Oppenheim M. Former Victoria's Secret model Erin Heatherton says she left the company after being told to lose weight. The Independent [Internet]. 2016; Available from: http://www.independent.co.uk/news/people/victorias-secret-erin-heathertonweight-loss-body-image-lingerie-img-a6970671.html

17. Zancu SA, Enea V. Eating disorders among fashion models: A systematic review of the literature. Eat Weight Disord. 2017;22:395-405.

18. Preti A, Usai A, Miotto P, Petretto DR, Masala C. Eating disorders among professional fashion models. Psychiatry Res. 2008;159:86-94.

19. Santonastaso P, Mondini S, Favaro A. Are fashion models a group at risk for eating disorders and substance abuse? Psychother Psychosom. 2002;71:168-72.

20. Brenner JB, Cunningham JG. Gender differences in eating attitudes, body concept and self- esteem among models. Sex Roles. 1992;27:413-37.

21. Aalten A. "The moment when it all comes together": Embodied experiences in ballet. Eur J Women's Stud. 2004;11:263-76.

22. Clabaugh A, Morling B. Stereotype accuracy of ballet and modern dancers. J Soc 
Psychol. 2004;144:31-48.

23. Schluger AE. Disordered eating attitudes and behaviors in female college dance students: Comparison of modern dance and ballet dance majors. N Am J Psychol. 2010;12:117-28.

24. Langdon SW, Petracca G. Tiny dancer: Body image and dancer identity in female modern dancers. Body Image [Internet]. Elsevier Ltd; 2010;7(4):360-3. Available from: http://dx.doi.org/10.1016/j.bodyim.2010.06.005

25. Bettle N, Bettle O, Neumärker U, Neumärker K-J. Adolescent ballet school students: Their quest for body weight change. Psychopathology. 1998;31:153-9.

26. Anshel MH. Sources of disordered eating patterns between ballet dancers and nondancers. J Sport Behav. 2004;27(2):115-33.

27. Nerini A. Media influence and body dissatisfaction in preadolescent ballet dancers and non-physically active girls. Psychol Sport Exerc. 2015;20:76-83.

28. Ravaldi C, Vannacci A, Bolognesi E, Mancini S, Faravelli C, Ricca V. Gender role, eating disorder symptoms, and body image concern in ballet dancers. J Psychosom Res. 2006;61:529-35.

29. Neumärker K-J, Bettle N, Neumärker U, Bettle O. Age- and gender-related psychological characteristics of adolescent ballet dancers. Psychopathology. 2000;33:137-42.

30. Ringham R, Klump K, Kaye W, Stone D, Libman S, Stowe S, et al. Eating disorder symptomatology among ballet dancers. Int J Eat Disord. 2006;39:503-8.

31. Swami V, Harris AS. Dancing toward positive body image? Examining body-related constructs with ballet and contemporary dancers at different levels. Am J Danc Ther. $2012 ; 34: 39-52$

32. Pollatou E, Bakali N, Theodorakis Y, Goudas M. Body image in female professional 
and amateur dancers. Res Danc Educ. 2010;11:131-7.

33. Doumenc A, Sudres JL, Sztulman H. Approche des dimensions pondérales et corporelles de jeunes danseuses classiques amatrices vs professionnelles [Approach to the weight and body dimensions of young amateur vs. professional dancers]. Neuropsychiatr Enfance Adolesc. 2005;53:299-308.

34. Toro J, Guerrero M, Sentis J, Castro J, Puértolas C. Eating disorders in ballet dancing students: Problems and risk factors. Eur Eat Disord Rev. 2009;17:40-9.

35. Goodwin H, Arcelus J, Marshall S, Wicks S, Meyer C. Critical comments concerning shape and weight: Associations with eating psychopathology among full-time dance students. Eat Weight Disord. 2014;19:115-8.

36. de Bruin AP, Bakker F, Oudejans R. Achievement goal theory and disordered eating: Relationships of disordered eating with goal orientations and motivational climate in female gymnasts and dancers. Psychol Sport Exerc. 2009;10:72-9.

37. Nordin-Bates SM, Schwarz JFA, Quested E, Cumming J, Aujla IJ, Redding E. Withinand between-person predictors of disordered eating attitudes among male and female dancers: Findings from the UK Centres for Advanced Training. Psychol Sport Exerc. Elsevier Ltd; 2016;27:101-11.

38. Sundgot-Borgen J, Torstveit M. Prevalence of eating disorders in elite athletes is higher than in the general population. Clin J Sport Med. 2004;14:25-32.

39. Yeager KK, Agostini R, Nattiv A, Drinkwater B. The female athlete triad: Disordered eating, amenorrhea, osteoporosis. Med Sci Sports Exerc. 1993;25:775-7.

40. Nattiv A, Loucks AB, Manore MM, Sanborn CF, Sundgot-Borgen J, Warren MP. The female athlete triad. Med Sci Sports Exerc. 2007;39:1867-82.

41. Mountjoy M, Sundgot-Borgen J, Burke L, Carter S, Constantini N, Lebrun C, et al. The IOC consensus statement: beyond the Female Athlete Triad-Relative Energy 
Deficiency in Sport (RED-S). Br J Sports Med. 2014;48:491-7.

42. Melin A, Torstveit M, Burke L, Marks S, Sundgot-Borgen J. Disordered eating and eating disorders in aquatic sports. Int J Sport Nutr Exerc Metab. 2014;24:450-9.

43. Torstveit M, Sundgot-Borgen J. Participation in leanness sports but not training volume is associated with menstrual dysfunction: A national survey of 1276 elite athletes and controls. Br J Sports Med. 2005;39:141-7.

44. Torstveit M, Sundgot-Borgen J. The female athlete triad: Are elite athletes at increased risk? Med Sci Sports Exerc. 2005;37(2):184-93.

45. Milligan B, Pritchard M. The relationship between gender, type of sport, body dissatisfaction, self esteem and disordered eating behaviors in Division I athletes. Athl Insight. 2006;8:1-15.

46. Francisco R, Narciso I, Alarcão M. Individual and relational risk factors for the development of eating disorders in adolescent aesthetic athletes and general adolescents. Eat Weight Disord. 2013;18:403-11.

47. Thiemann P, Legenbauer T, Vocks S, Platen P, Auyeung B, Herpertz S. Eating disorders and their putative risk factors among female German professional athletes. Eur Eat Disord Rev. 2015;23(4):269-76.

48. Smolak L, Murnen SK, Ruble AE. Female athletes and eating problems: A metaanalysis. Int J Eat Disord. 2000;27:371-80.

49. Krentz EM, Warschburger P. A longitudinal investigation of sports-related risk factors for disordered eating in aesthetic sports. Scand J Med Sci Sport. 2013;23:303-10.

50. Hausenblas HA, Downs DS. Comparison of body image between athletes and nonathletes: A meta-analytic review. J Appl Sport Psychol. 2001;323-39.

51. Krentz EM, Warschburger P. Sports-related correlates of disordered eating in aesthetic sports. Psychol Sport Exerc. 2011;12:375-82. 
52. Russell K. On versus off the pitch: The transiency of body satisfaction among female rugby players, cricketers, and netballers. Sex Roles. 2004;51:561-74.

53. de Bruin AP, Oudejans R, Bakker F, Woertman L. Contextual body image and athletes' disordered eating: The contribution of athletic body image to disordered eating in high performance women athletes. Eur Eat Disord Rev. 2011;19:201-15.

54. Bachner-Melman R, Zohar AH, Ebstein RP, Elizur Y, Constantini N. How anorexiclike are the symptom and personality profiles of aesthetic athletes? Med Sci Sports Exerc. 2006;38:628-36.

55. Leung F, Geller J, Katzman M. Issues and concerns associated with different risk models for eating disorders. Int J Eat Disord. 1996;19(3):249-56.

56. Thompson RA, Sherman RT. "Good athlete" traits and characteristics of Anorexia Nervosa: Are they similar? Eat Disord. 1999;7:181-90.

57. Galli N, Petrie T, Chatterton J. Team weigh-ins and self-weighing: Relations to bodyrelated perceptions and disordered eating in collegiate male athletes. Psychol Sport Exerc. 2017;29:51-5.

58. Muscat AC, Long BC. Critical comments about body shape and weight: Disordered eating of female athletes and sport participants. J Appl Sport Psychol. 2008;20:1-24.

59. de Bruin AP, Oudejans R, Bakker F. Dieting and body image in aesthetic sports: A comparison of Dutch female gymnasts and non-aesthetic sport participants. Psychol Sport Exerc. 2007;8(4):507-20.

60. Nowicka P, Eli K, Ng J, Apitzsch E, Sundgot-Borgen J. Moving from knowledge to action: A qualitative study of elite coaches' capacity for early intervention in cases of eating disorders. Int J Sport Sci Coach. 2013;8:343-56.

61. Piran N. Eating disorders: A trial of prevention in a high risk school setting. J Prim Prev [Internet]. 1999;20:75-90. Available from: 
http://search.ebscohost.com/login.aspx?direct=true \&db=eoah\&AN=4276601\&site=eh ost-live \&scope $=$ site

62. Bar RJ, Cassin SE, Dionne MM. The long-term impact of an eating disorder prevention program for professional ballet school students: A 15-year follow-up study. Eat Disord [Internet]. Routledge; 2017;25(5):375-87. Available from: https://www.tandfonline.com/doi/full/10.1080/10640266.2017.1308731

63. Nordin-Bates SM, Walker IJ, Redding E. Correlates of disordered eating attitudes among male and female young talented dancers: Findings from the UK centres for advanced training. Eat Disord. 2011;19:211-33.

64. Neumärker K-J, Bettle N, Bettle O, Dudeck U, Neumärker U. The eating attitudes test: Comparative analysis of female and male students at the Public Ballet School of Berlin. Eur Child Adolesc Psychiatry. 1998;7:19-23. 


\section{Table 1.}

Summary of the reviewed studies on fashion models

\begin{tabular}{|l|c|c|l|}
\hline \multicolumn{1}{|c|}{ Author(s) } & Year & Type of study * & \\
\hline Garner \& Garfinkel (1) & 1980 & Quant, Cr & Female modeling students and other groups (ballet students, patients with \\
& & & AN, music students and controls) \\
\hline Brenner \& Cunningham (20) & 1992 & Quant, Cr & Male and female professional fashion models and controls \\
\hline Santonastaso, Mondini, \& Favaro (19) & 2002 & Quant, Cr & Female professional fashion models and controls \\
\hline Preti, Usai, Miotto, Petretto, \& Masala (18) & 2008 & Quant, Cr & Female professional fashion models and controls \\
\hline Swami \& Szmigielska (10) & 2013 & Quant, Cr & Female professional fashion models and controls \\
\hline
\end{tabular}

* Cr. cross-sectional; Quant. Quantitative. 


\section{Table 2.}

Summary of the reviewed studies on dancers

\begin{tabular}{|c|c|c|c|}
\hline Author(s) & Year & $\begin{array}{l}\text { Type of } \\
\text { study* }\end{array}$ & Sample \\
\hline Garner \& Garfinkel (1) & 1980 & Quant, Cr & $\begin{array}{l}\text { Female professional ballet students and other groups (modeling students, } \\
\text { patients with AN, music students and controls) }\end{array}$ \\
\hline Bettle, Bettle, Neumärker \& Neumärker (25) & 1998 & Quant, Cr & Male and female adolescent ballet dancers and controls \\
\hline Neumärker, Bettle, Bettle, Dudeck \& Neumärker (64) & 1998 & Quant, Cr & Male and female adolescent ballet dancers, patients with AN and controls \\
\hline Neumärker, Bettle, Neumärker \& Bettle (29) & 2000 & Quant, Cr & Male and female adolescent ballet dancers and controls \\
\hline Anshel (26) & 2004 & Quant, Cr & Female adolescent ballet dancers and controls \\
\hline Doumenc, Sudres \& Sztulman (33) & 2005 & Quant, Cr & Female professional ballet students and amateurs \\
\hline $\begin{array}{l}\text { Ravaldi, Vannacci, Bolognesi, Mancini, Faravelli \& } \\
\text { Ricca (28) }\end{array}$ & 2006 & Quant, Cr & $\begin{array}{l}\text { Female non-elite ballet dancers, female gymnasium users, male non- } \\
\text { competitive body builders, female and male controls }\end{array}$ \\
\hline $\begin{array}{l}\text { Ringham, Klump, Kaye, Stone, Libman, Stowe et al. } \\
\text { (30) }\end{array}$ & 2006 & Quant, Cr & Female ballet dancers, patients with $\mathrm{AN}$ and $\mathrm{BN}$, and controls \\
\hline Aalten (11) & 2007 & Qual, Cr & Female professional ballet dancers and dance students \\
\hline Gvion (7) & 2008 & Qual, Cr & Female professional ballet students \\
\hline de Bruin, Bakker \& Oudejans (36) & 2009 & Quant, Cr & Female artistic gymnasts and modern dancers \\
\hline
\end{tabular}




\begin{tabular}{|c|c|c|c|}
\hline Toro, Guerrero, Sentis, Castro \& Puértolas (34) & 2009 & Quant, Cr & Female adolescent dance students and controls \\
\hline Langdon \& Petracca (24) & 2010 & Quant, Cr & Female modern dancers (and controls from previous studies) \\
\hline Pollatou, Bakali, Theodorakis \& Goudas (32) & 2010 & Quant, Cr & Female professional and amateur dancers \\
\hline Schluger (23) & 2010 & Quant, Cr & Female modern and ballet dancers \\
\hline Nordin-Bates, Walker \& Redding (63) & 2011 & Quant, Cr & Male and female professional dance students \\
\hline Francisco, Alarcão \& Narciso (9) & 2012 & Qual, Cr & Male and female professional ballet students and elite gymnasts \\
\hline Francisco, Narciso \& Alarcão (2) & 2012 & Quant, Cr & Male and female ballet dancers and gymnasts \\
\hline Swami \& Harris (31) & 2012 & Quant, Cr & Female ballet and contemporary dancers \\
\hline Goodwin, Arcelus, Marshall, Wicks \& Meyer (35) & 2014 & Quant, Cr & Female dance students \\
\hline Kong \& Harris (3) & 2015 & Quant, Cr & $\begin{array}{l}\text { Female athletes from leanness focused (including dance) and nonleanness } \\
\text { focused sports }\end{array}$ \\
\hline Nerini (27) & 2015 & Quant, Cr & Female preadolescent ballet dancers and controls \\
\hline $\begin{array}{l}\text { Nordin-Bates, Schwarz, Quested, Cumming, Aujla \& } \\
\text { Redding (37) }\end{array}$ & 2016 & Quant, Cr & Male and female professional dance students \\
\hline
\end{tabular}

* Cr. cross-sectional; L. longitudinal; Quant. Quantitative; Qual. Qualitative. 
Table 3.

Summary of the reviewed studies on aesthetic athletes

\begin{tabular}{|c|c|c|c|}
\hline Author(s) & Year & $\begin{array}{l}\text { Type of } \\
\text { study* }\end{array}$ & Sample \\
\hline Byrne \& McLean (6) & 2002 & Quant, Cr & $\begin{array}{l}\text { Male and female elite athletes from leanness focused and nonleanness } \\
\text { focused sports and controls }\end{array}$ \\
\hline Sundgot-Borgen \& Torstveit (38) & 2004 & Quant, Cr & $\begin{array}{l}\text { Male and female elite athletes (from aesthetic and other sports) and } \\
\text { controls }\end{array}$ \\
\hline Torstveit \& Sundgot-Borgen (43) & 2005 & Quant, Cr & Female elite athletes (from aesthetic and other sports) and controls \\
\hline Torstveit \& Sundgot-Borgen (44) & 2005 & Quant, Cr & Female elite athletes (from aesthetic and other sports) and controls \\
\hline $\begin{array}{l}\text { Bachner-Melman, Zohar, Ebstein, Elizur \& Constantini } \\
\text { (54) }\end{array}$ & 2006 & Quant, Cr & Female aesthetic and nonaesthetic athletes, patients with AN, and controls \\
\hline Kerr, Berman \& De Souza (8) & 2006 & $\begin{array}{l}\text { Quant+Q } \\
\text { ual, } \mathrm{Cr}\end{array}$ & Female current and retired artistic gymnasts, parents, coaches and judges \\
\hline Milligan \& Pritchard (45) & 2006 & Quant, Cr & Male and female lean and non-lean sport athletes \\
\hline de Bruin, Oudejans \& Bakker (59) & 2007 & Quant, Cr & Female elite and non-elite and gymnasts, and controls \\
\hline Muscat \& Long (58) & 2008 & Quant, Cr & Female athletes and sport participants \\
\hline de Bruin AP, Bakker F, Oudejans (36) & 2009 & Quant, Cr & Female artistic gymnasts and modern dancers \\
\hline
\end{tabular}




\begin{tabular}{|c|c|c|c|}
\hline de Bruin, Oudejans, Bakker \& Woertman (53) & 2011 & Quant, Cr & Female aesthetic or endurance athletes and other sport participants \\
\hline Krentz \& Warschburger (51) & 2011 & & Male and female elite athletes from aesthetic sports \\
\hline Francisco, Alarcão \& Narciso (9) & 2012 & Qual, Cr & Male and female elite gymnasts and professional ballet students \\
\hline Francisco, Narciso \& Alarcão (2) & 2012 & Quant, Cr & Male and female elite and non-elite gymnasts and ballet dancers \\
\hline Francisco, Narciso \& Alarcão (46) & 2013 & Quant, Cr & $\begin{array}{l}\text { Male and female elite and non-elite gymnasts and ballet dancers, and } \\
\text { controls }\end{array}$ \\
\hline Krentz \& Warschburger (49) & 2013 & Quant, L & Male and female elite athletes from aesthetic sports \\
\hline Kong \& Harris (3) & 2015 & Quant, Cr & Female athletes from leanness and nonleanness focused sports \\
\hline $\begin{array}{l}\text { Thiemann, Legenbauer, Vocks, Platen, Auyeung \& } \\
\text { Herpertz (47) }\end{array}$ & 2015 & Quant, Cr & Female elite aesthetic and ball game sports athletes, and controls \\
\hline Galli, Petrie \& Chatterton (57) & 2017 & Quant, Cr & Male collegiate athletes from different sports \\
\hline
\end{tabular}

* Cr. cross-sectional; L. longitudinal; Quant. Quantitative; Qual. Qualitative. 